\title{
Comparative morphology of immature Trictenotoma formosana Kriesche, 1919 and systematic position of the Trictenotomidae (Coleoptera, Tenebrionoidea)
}

\author{
Fang-Shuo HU ${ }^{1}$, Darren A. POLLOCK ${ }^{2} \&$ Dmitry TELNOV ${ }^{3, *}$ \\ ${ }^{1}$ Department of Entomology, National Chung Hsing University, 145 Xingda Road, \\ South District, 40227 Taichung, Taiwan. \\ ${ }^{2}$ Department of Biology, Eastern New Mexico University, Portales, NM, USA. \\ ${ }^{3}$ Natural History Museum, Department of Life Sciences, Cromwell Road, \\ SW7 5BD London, United Kingdom. \\ ${ }^{3}$ Institute of Biology, University of Latvia, Miera iela 3, LV-2169, Salaspils, Latvia. \\ *Corresponding author: anthicus@gmail.com \\ ${ }^{1}$ Email: fangshuo_hu@smail.nchu.edu.tw \\ ${ }^{2}$ Email: darren.pollock@enmu.edu \\ ${ }^{1}$ urn:1sid:zoobank.org:author:49A66DB4-625F-4CD6-9512-1AE6396F4851 \\ ${ }^{2}$ urn:1sid:zoobank.org:author:A9B3DFD3-6391-4E1D-8894-53B148A3322B \\ ${ }^{3}$ urn:Isid:zoobank.org:author:F78B0D3E-E409-4054-A834-E6C06918B62F
}

\begin{abstract}
Detailed description and illustrations of immature Trictenotoma Gray, 1832 (Trictenotomidae Blanchard, 1845) are presented for the first time, based on larvae and pupae of T. formosana Kriesche, 1919. Characters exhibited by the mature larva are similar to those described by Gahan (1908) for T. childreni Gray, 1832, which was based on a single specimen. The phylogenetic position of Trictenotomidae has varied among Scarabaeoidea, Chrysomeloidea and Tenebrionoidea, though recent studies place the family clearly among the latter. Features of the immature stages described here corroborate this placement. Evidence supports placement within or near the "salpingid group" (Pythidae, Salpingidae, Boridae, Pyrochroidae). Distinguishing features of the mature trictenotomid larva include the absence of stemmata, antennal sensorium, urogomphal pit(s) and lip, the presence of paired series of longitudinal ridges on the meso- and metathorax and abdominal tergites $1-8$ and sternites $2-8$, a paired arcuate row of 12-15 asperities on the anterior margin of sternite 9 and relatively short, upturned urogomphi. The systematic position of trictenotomids within the Tenebrionoidea Latreille, 1802 is confirmed. The phylogenetic relationships among Trictenotomidae and other "salpingid group" members (e.g., Pythidae Solier, 1834 and Salpingidae Leach, 1815) are highlighted and discussed, solving an almost two centuries old puzzle in Coleoptera systematics.
\end{abstract}

Keywords. Larva, pupa, phylogeny, salpingid group.

Hu F.-S., Pollock D.A. \& Telnov D. 2020. Comparative morphology of immature Trictenotoma formosana Kriesche, 1919 and systematic position of the Trictenotomidae (Coleoptera, Tenebrionoidea). European Journal of Taxonomy 640: 1-22. https://doi.org/10.5852/ejt.2020.640 


\section{Introduction}

Trictenotomidae Blanchard, 1845 is a small family of Coleoptera Linnaeus, 1758 with two extant genera (Trictenotoma Gray, 1832 and Autocrates Thomson, 1860) with 10 and 5 species, respectively (Gebien 1911; Telnov 1999; Drumont 2006, 2016; Drumont \& Telnov 2009). No fossil record is yet known for this group. Trictenotomids are distributed in most of southern and eastern Asia from the southern foothills of the Himalaya, central and eastern China and Korean Peninsula in the north towards the Greater Sunda Islands of Java and Borneo, and the Philippine Archipelago in the south (Telnov 1999; Telnov \& Lee 2008; Drumont \& Telnov 2009; Drumont et al. 2019).

Presumably because of their large size and appearance, adult trictenotomids have attracted the interest of several generations of coleopterists, both professionals and amateurs. The systematic placement of this coleopterous family has been disputed since the description of the first species of Trictenotoma and probably even earlier. The first described taxa of Trictenotomidae were initially placed in two different families of two different superfamilies based on the external morphology of adults: Lucanidae Latreille, 1804 of Scarabaeoidea Latreille, 1802 (Trictenotoma childreni Gray, 1832, type species of Trictenotoma) (Gray 1832) and Cerambycidae Latreille, 1802 (or "Longicornes") of Chrysomeloidea Latreille, 1802 (Autocrates aeneus (Westwood, 1846), type species of Autocrates) (Westwood 1848). By their appearance - large body, enlarged male mandibles, spinose lateral pronotal margins and threesegmented apical antennal club - these enigmatic beetles resemble lucanids or Prioninae Latreille, 1802 (Cerambycidae) which has led to confusion by earlier authors. However, trictenotomids are readily distinguishable from both Lucanidae and Cerambycidae by, among other features, the 5-5-4 tarsal formula. Lameere (1916) stated that Trictenotomidae certainly belongs to the heteromerous Coleoptera (superfamily Tenebrionoidea Latreille, 1802). Recent analyses, based either on morphological (e.g., Lameere 1916; Crowson 1955, 1981; Watt 1987; Pollock 1994) or molecular (Kergoat et al. 2014; McKenna et al. 2015; Batelka et al. 2016; Zhang et al. 2018) characters of adults and larvae (based on the only description of a larval trictenotomid, that of Gahan 1908) have confirmed this tenebrionoid placement and have disproved the earlier placements in Lucanidae or Cerambycidae.

Until very recently, the only published information on immature trictenotomids was the description of a presumptive larva of $T$. childreni by Gahan (1908). The association was based on the fact that the described larva was found "by the side of the debris of pupae and imagines of Trictenotoma childreni, Gray". Despite not being reared to confirm its identity, there is no reason to doubt the provisional determination as T. childreni (Pollock \& Telnov 2010), especially since Gahan's description and figure of the larva matches closely that of the mature larva of Trictenotoma formosana Kriesche, 1919 described here. Gahan's incomplete description also lacked any natural history information. This specimen, supposedly in poor condition (Pollock \& Telnov 2010), could not be located by the third author in the larval Coleoptera collection at the Natural History Museum, London, in 2019.

The natural history and behaviour of immature Trictenotomidae remained unknown until Lin \& $\mathrm{Hu}$ $(2018,2019)$ described the process of oviposition and other bionomic characteristics of the endemic Taiwanese T.formosana. This recent work of Lin \& $\mathrm{Hu}(2018,2019)$ and the immature stage descriptions included herein was based on Trictenotoma formosana Kriesche, 1919, an endemic species of Taiwan with the type locality in the southern part of the island (Kriesche 1919). This species is found in forest habitats all across the island, except for high montane areas (Hu, unpublished).

The objectives of this paper are to describe and illustrate immature stages of the Trictenotomidae based on first-instar, mature larva and pupa of T. formosana, and discuss the phylogenetic relationships of the family and settle an almost two centuries-long discussion on the systematic position of this group. Placement of the Trictenotomidae within Tenebrionoidea is fully supported by our results. 
HU F.-S. et al., Comparative morphology of immature Trictenotomidae

\section{Material and methods}

\section{Preparation and depositories}

All specimens described and illustrated in this paper are from the material described by Lin \& $\mathrm{Hu}(2018$, 2019). Specimens were killed in boiling water. Fractions of $60 \%, 70 \%, 80 \%$, and $95 \%$ ethanol were used to dehydrate tissues, 5 minutes per concentration. After dehydration, larvae and pupae were preserved permanently in $95 \%$ ethanol.

Voucher specimens are deposited in the collections of the Eastern New Mexico University, Portales (USA), the National Museum of Natural Sciences, Taichung (Taiwan) and the Natural History Museum, London (United Kingdom).

\section{Examination and illustration of specimens}

Habitus images of the last-instar larva and pupa were made from live specimens. The live specimens were kept at $7{ }^{\circ} \mathrm{C}$ temperature for 10 minutes prior to taking the images. Ethanol-preserved specimens were also used for imaging to provide higher magnification details. Antenna, mandible, maxilla and legs were dissected for imaging, including those of the last-instar. A Leica M205C stereo microscope and Leica DM750 compound microscope were used for dissection and study. Habitus images of the first-instar larva were taken using a Canon EOS 760D SLR camera with a Canon MP-E65 f2.8 1-5 × macro lens. An Olympus OM-D E-M1 digital camera with an Olympus M. ZUIKO DIGITAL ED $30 \mathrm{~mm}$ F3.5 micro lens was used to image the habitus of the last-instar larva, head, thorax, tergites and sternites of the lastinstar larva, as well as the detailed structures and habitus of the pupa. Images of the antenna, mandible, maxilla, leg and eyes of the first-instar larva were taken with a Leica M205C stereo microscope and a Leica MC170 HD digital camera attached to this stereo microscope, using LAS software (ver. 4.4.0, Leica Application Suite, Wetzlar, Germany). CombineZP software was used for image stacking (Hadley 2010). Further image manipulations were done in either Adobe Photoshop CS5 or Adobe Illustrator CS5.

\section{Results}

Class Insecta Linnaeus, 1758

Order Coleoptera Linnaeus, 1758

Family Trictenotomidae Blanchard, 1845

Genus Trictenotoma Gray, 1832

Trictenotoma formosana Kriesche, 1919

Figs $1-27$

\section{Description}

Last-instar larva (Figs 1-17, 27)

LARVA. Tenebrionoid. Body elongate (body length: $77.3 \mathrm{~mm}(74-83 \mathrm{~mm}, \mathrm{n}=4)$, from mandibles to posterior extent of urogomphi), parallel-sided, slightly to moderately flattened dorsoventrally; colour pale yellow, darker on anterior half of head (including mouthparts, antennae, maxillary labial palps), tarsunguli and apices of urogomphi. Basal half of head, legs, and bases of urogomphi reddish-brown. Dorsal and ventral surfaces of body (excluding legs) with two distinct types of ornamentation: scattered, elongate setae in a regular pattern on tergites and sternites; and narrow, sclerotized, longitudinally oriented ridges (the latter often very short and tubercle-like, especially on venter of meso- and metathorax) medially on most sternites and tergites.

HEAD (Figs 3-4,27). Prognathous, exserted from prothorax, with lateral edges slightly and evenly rounded; dorsal surface punctate, somewhat rugose, with sparse, elongate setae; dorsolateral setae as follows: 


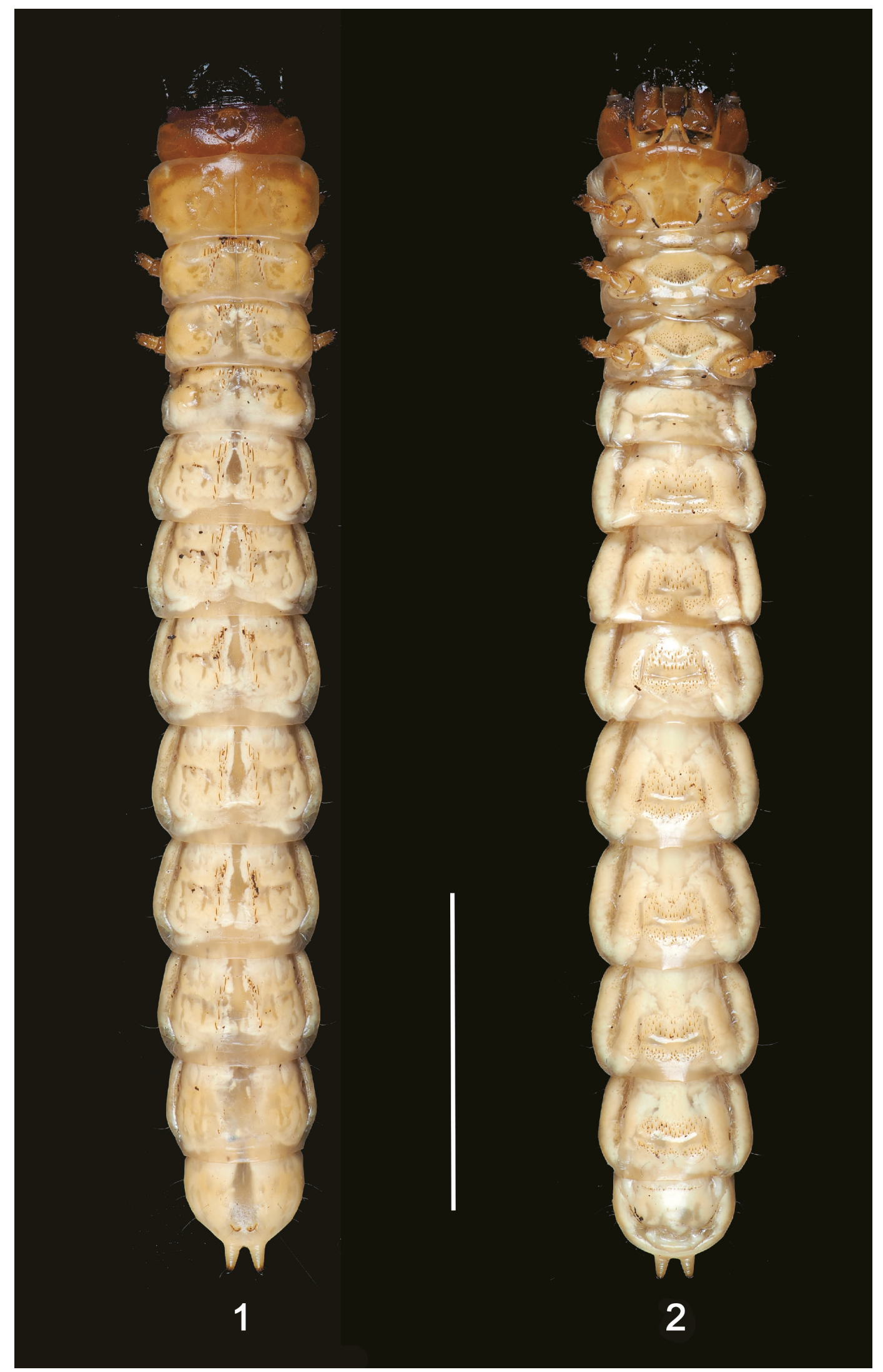

Figs 1-2. Habitus of last-instar larva of Trictenotoma formosana Kriesche, 1919. 1. Dorsal view. 2. Ventral view. Scale bar: $20 \mathrm{~mm}$. 
HU F.-S. et al., Comparative morphology of immature Trictenotomidae

oblique pair laterally on each side of clypeus; single seta on epicranial plate just laterad widest extent of lyriform frontal arms of epicranial suture; transverse pair on frons just anteriad anterior curve in frontal arms; several setae on lateral margins of epicranial plate mainly in anterior half; ventral setae as follows: transverse pair near base of antennae; several setae along moderately raised ventral epicranial ridges; epicranial suture with lyriform frontal arms, extending to just behind antennal insertions; epicranial stem very short; posterior edge of epicranial plate deeply incised medially, margins bisinuate; endocarinae absent; stemmata absent; labrum rectangular, about twice as wide as long, anterior corners rounded, with dense row of relatively stout setae along anterior margin. Mandibles (Figs 7-9) large, heavily sclerotized, asymmetrical, tridentate apically; inner margin of left mandible with distinct premolar tooth, slightly ventral in placement; mola present on both mandibles, larger on left mandible; mola on left mandible with two slightly dentate ridges, anteriormost larger; mola on right mandible with single ridge; molae with transverse ridges without dorsal asperities; dorsal microtrichiae absent; both mandibles with scattered, short setae especially on lateral margins. Maxillae (Fig. 5) with 2-segmented cardo and truncate mala; mala with a row of dense, moderately long spines along inner margin and a long (subequal in length to width across distal end of mala) acute split tooth on inner edge; stipes punctured, apically and on outer margin sparsely spinose. Maxillary articulating area distinct. Maxillary palpi 3-segmented, $2^{\text {nd }}$ maxillary palpomere longer than $1^{\text {st }}$ or $3^{\text {rd }}$ palpomere; distal maxillary palpomere narrowed apically. Labium without suture between gula and submentum (forming 'gulamentum'); submentum rectangular, slightly longer than wide, with a pair of setae at about midlength; mentum punctured, longer than wide and widest at its midlength, with pair of stiff setae along each lateral margin, suture between prementum and mentum not clear. Ligula absent (present in first instar, see below); labial palpi 3 -segmented, $2^{\text {nd }}$ labial palpomere longer than palpomere 1 or 3; apical labial palpomeres narrowed apically. Hypostomal ridges present; hypostomal rods absent. Antennae (Fig. 6) prominent, 3 -segmented; $2^{\text {nd }}$ antennomere shorter and narrower than basal antennomere; antennomere 3 short and narrow (ratio: 1.61: 1.16: 0.23). Sensorium absent. Antennomeres 1 and 2 with sparse setae especially along inner margins; antennomere 3 with few setae on apex.

THORAX (Figs 11-12). Prothorax transverse, subquadrate, approximately as long as combined lengths of meso- and metathorax; several setae on lateral margin and pair of setae near posterolateral corner; meso- and metathorax subequal in length, with inverted 'V-shaped' field of short longitudinal ridges along anterior margin, occupying middle $1 / 3$ of tergites; behind anterior field of ridges is another group of ridges, extending posteriorly as slightly curved line; dorsal setae of meso- and metathorax in similar positions: several along lateral margin, one near posterolateral angle and one slightly removed from lateral margin at about half length of segment; ventral surface of prothorax flat, with pair of setae near procoxal cavity, lacking longitudinal ridges; meso- and metathorax ventrally with a V-shaped impression at midlength, anterior to which is a dense field of longitudinal ridges (with a few ridges posteriad impressions). Mesothoracic spiracle annular, large and oval, laterotergite not distinctly produced. Legs (Fig. 10) 5-segmented, short, with spine-like, stiff, elongated setae especially on ventral and anterior surfaces; dorsal margin of femora distinctly curved, apex much wider than base; coxa with short setae; tarsungulus relatively short, stout, with constriction at or before midlength, without distinct spine or setae at its base.

AвDOMEN (Figs 13-17). Elongate, segments 1-8 subhexagonal, widest at about midlength; segment 1 slightly shorter than segment 2 , segments $2-8$ subequal in length and width; tergite 9 (Fig. 16) nearly half-circular (excluding urogomphi); tergite 9 slightly shorter and narrower than tergite 8; tergites 1-8 with distinct sinuous parabasal ridge and narrow 'V-shaped' field of moderately long longitudinal ridges; sternites 1-8 with a curved impression, two subparallel median impressions and a relatively dense field of short longitudinal ridges; spiracles annular, ovoid, moderately large. Sternite 9 (Fig. 15) with asperities along anterior margin, forming two slightly arcuate rows of 12-15 asperities each, outermost asperity larger than others; tergite 9 extended ventrally around anus, forming a series of small plates; tergite 9 


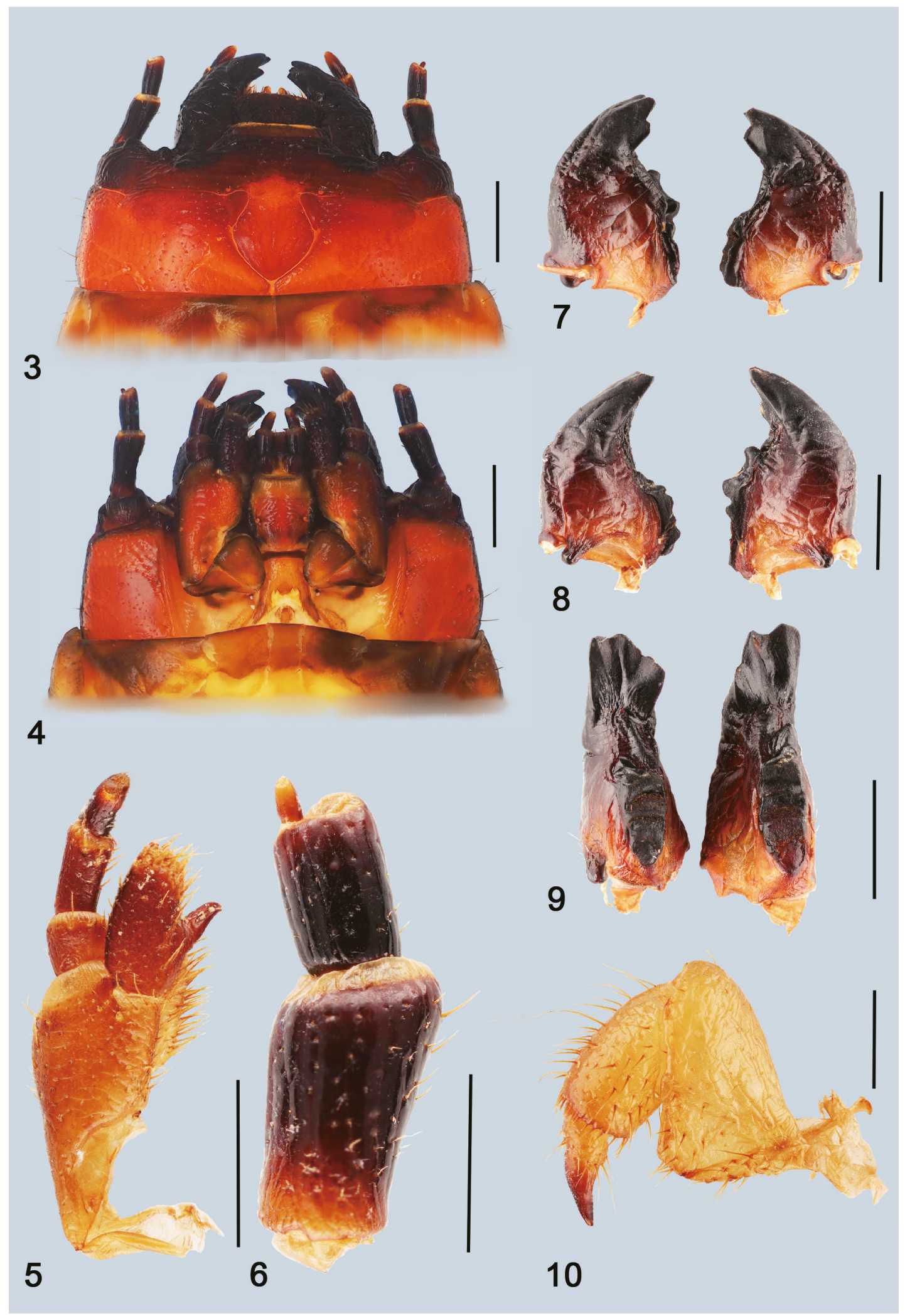

Figs 3-10. Head and fore leg of last-instar larva of Trictenotoma formosana Kriesche, 1919. 3. Head, dorsal view. 4. Head, ventral view. 5. Right maxilla, ventral view. 6. Left antenna, dorsal view. 7-9. Mandibles $(7=$ ventral view, $8=$ dorsal view, $9=$ mesal view $)$. 10. Left prothoracic leg. Scale bars: $3-4=3 \mathrm{~mm} ; 5,7-9=2 \mathrm{~mm} ; 6,10=1 \mathrm{~mm}$. 


\section{HU F.-S. et al., Comparative morphology of immature Trictenotomidae}

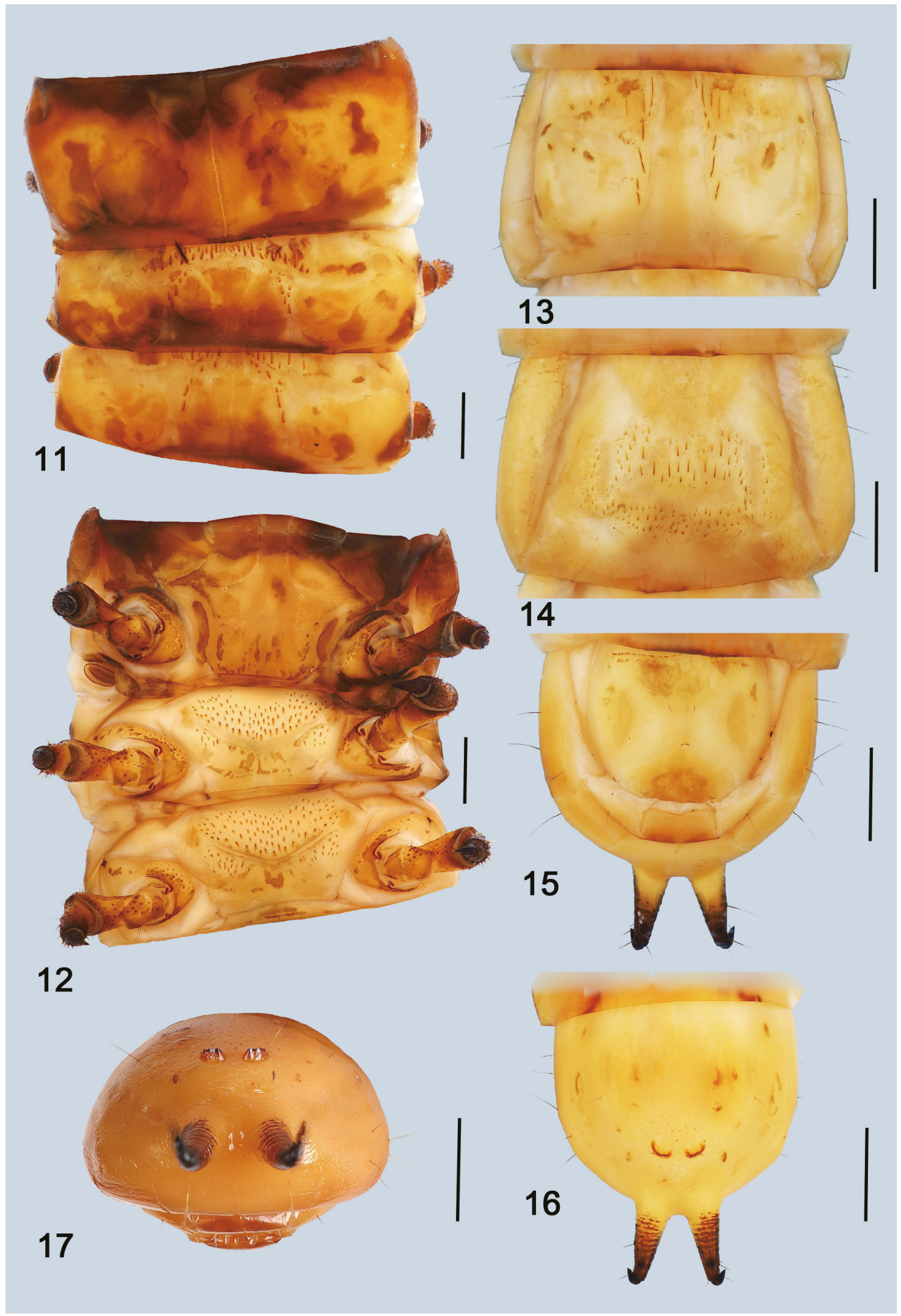

Figs 11-17. Thorax and abdominal segments 5 and 9 of last-instar larva of Trictenotoma formosana Kriesche, 1919. 11-12. Thorax $(11=$ dorsal view, $12=$ ventral view). 13. Tergite 5. 14. Sternite 5. 15. Sternite 9. 16. Tergite 9. 17. Abdominal segment 9, posterior view. Scale bars: $3 \mathrm{~mm}$. 
(Fig. 16) relatively densely punctate medially (especially compared to anterior tergites), with two small U-shaped predistal protrusions, each bearing an inconspicuous erect seta; dorsal setae placed similarly on tergites 2-8: several long setae along lateral margin, pair of setae on each side along posterior margin towards midline; scattered short setae among medial ridges, one or two setae on posterior half of tergites towards posterolateral margin; ventral setae as follows: two short setae on each side medially, near anterior edge of ridge field; one seta just posterior to ridge field, one or two setae near posterolateral corner. Urogomphi (Figs 15-17) short, hook-like, curved dorsally, outer margins subparallel and inner margins divergent posteriorly; several moderately long setae on distal half of urogomphi; urogomphal pit(s) and lip absent.

First-instar larva (Figs 18-26)

BoDy. Elongate (body length: $1.66 \mathrm{~mm}(1.47-1.81 \mathrm{~mm}, \mathrm{n}=20)$ from mandibles to urogomphi), parallelsided, flattened dosorventrally. Colour translucent-yellow, darker on apices of mandibles; dorsal and ventral surfaces of body (excluding legs) with two distinct types of ornamentation: scattered, elongate setae in a regular pattern on tergites and sternites; and narrow, short spines medially on most sternites and tergites.

HEAD (Figs 20-21, 26). Prognathous, exserted from prothorax, with lateral edges slightly and evenly rounded; head slightly wider than long; dorsal surface glossy, not punctate, with sparse, elongate setae; dorsolateral setae as follows: six pairs on labrum (two pairs on apex, three pairs on lateral surface, one pair on middle near base), two pairs on each side of clypeus, a pair on frons near base of antennae, a pair on frons just anteriad of anterior curve in frontal arms, a pair in front of stemmatal complex, three pairs behind stemmatal complex, a pair of long setae between frontal arms and stemmatal complex, a pair in middle of epicranial plate, a pair between stemmatal complex and base of head; ventral setae as follows: two pairs on oblique-frontal frons, a pair near base of stipes, another pair below this pair; epicranial suture with short lyriform frontal arms; epicranial stem indistinct; endocarinae absent; 5 stemmata on each side (Fig. 26), forming anterior column of 3 and posterior column of 2; labrum half-circular. Mandibles sclerotized, slightly asymmetrical, tridentate apically; mola not clear on either mandible; both mandibles with an inner tooth. Maxillae with 2-segmented cardo and truncate mala; mala with a row of dense, moderately long spines along inner margin and a truncated tooth on inner edge; few spines on apex of truncated tooth; stipes with four setae on each side. Maxillary articulating area distinct. Maxillary palpi 3-segmented, $2^{\text {nd }}$ maxillary palpomere longer than $1^{\text {st }}$ or $3^{\text {rd }}$ palpomere; apical maxillary palpomere narrowed apically. Labium without suture between gula and submentum (forming 'gulamentum'); submentum rectangular, slightly longer than wide; mentum wider than long and widest at midlength, with pair of stiff setae in middle; suture between prementum and mentum not clear. Ligula present; labial palpi 3-segmented, $2^{\text {nd }}$ labial palpomere longer than palpomere 1 or 3 . Hypostomal ridges and hypostomal rods absent. Antennae prominent, 3 -segmented; $2^{\text {nd }}$ antennomere longer and wider than basal antennomere; antennomere 3 short and narrow; sensorium absent. Antennomere 1 with single seta on inner margin; antennomere 2 with four apical setae.

THORAX (Figs 22-23). Prothorax transverse, subquadrate, approximately as long as combined lengths of meso- and metathorax; dorsolateral setae and spines as follows: pair of long setae on anterior one fourth of prothorax, pair of short spines near this pair of setae; pair of setae on antero-lateral part of prothorax; two pairs of setae on lateral margin of prothorax; pair of setae on posterior-lateral part of prothorax; pair of setae on base of prothorax; three pairs of short spines near frontal margin of mesothorax; two pairs of setae on lateral margin of mesothorax; pair of setae on base of mesothorax; two pairs of short spines on frontal margin of metathorax; pair of setae on antero-lateral part of metathorax; two pairs of setae on lateral margin of metathorax; pair of setae on base of metathorax; ventral spines as follows: five pairs of spines spread on frontal half of prothorax; a pair of short spines on frontal margin of mesothorax 
and metathorax. Mesothoracic spiracle annular and round. Legs 5-segmented, with spine-like, stiff, elongated setae especially on ventral and anterior surfaces.

Aвdomen (Figs 22-25). Elongate, segments 1-8 subhexagonal, length and width similar in all segments; tergite 9 (Fig. 24) nearly half-circular (excluding urogomphi); tergite 9 slightly longer and narrower than tergite 8 ; dorsolateral setae and spines of tergites $2-8$ (Fig. 22) as follows: two pairs of spines near middle of tergites; with pair of setae near lateral margin of tergites on both sides; pair of long setae

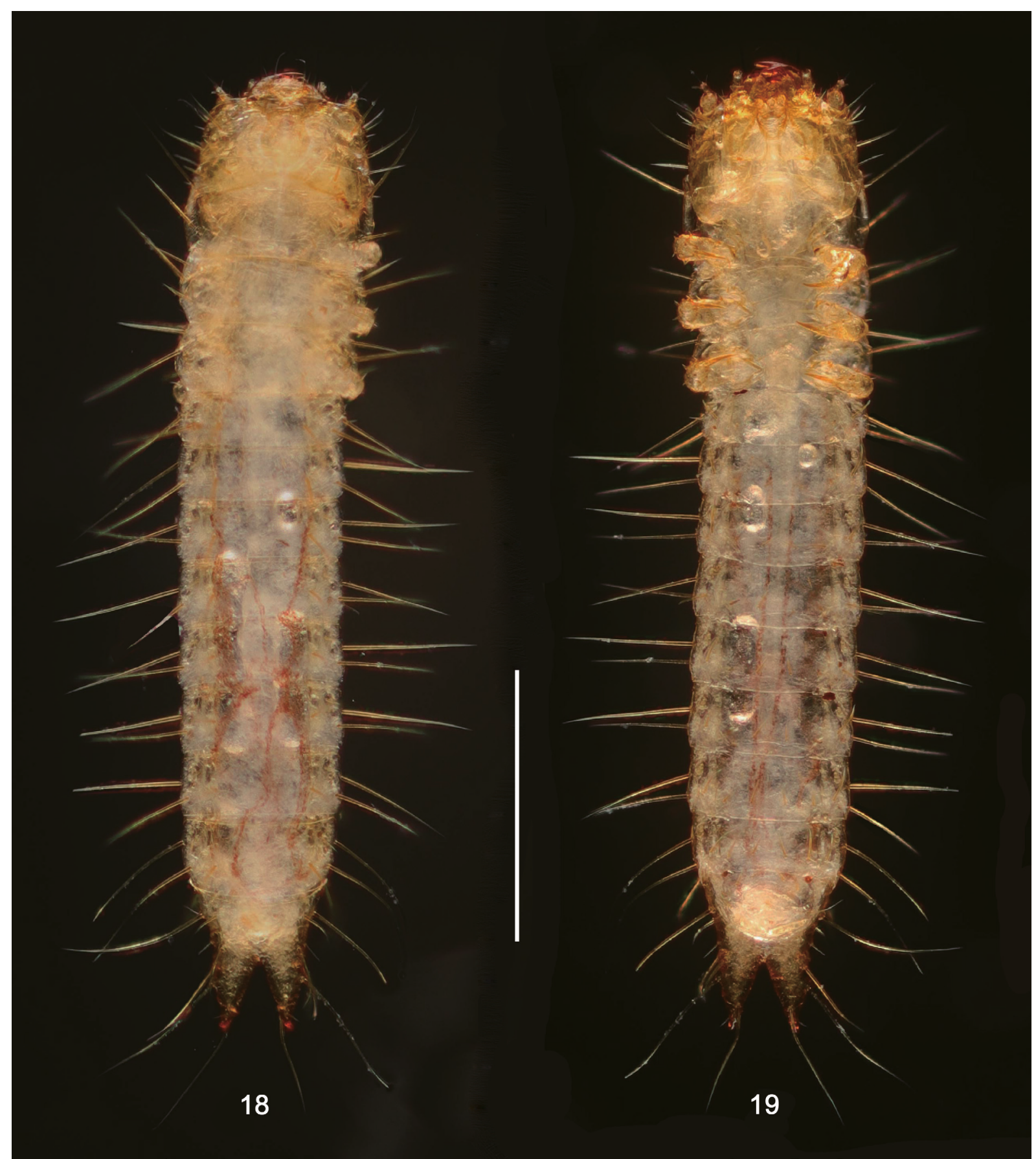

Figs 18-19. Habitus of first-instar larva of Trictenotoma formosana Kriesche, 1919. 18. Dorsal view. 19. Ventral view. Scale bar: $0.5 \mathrm{~mm}$. 


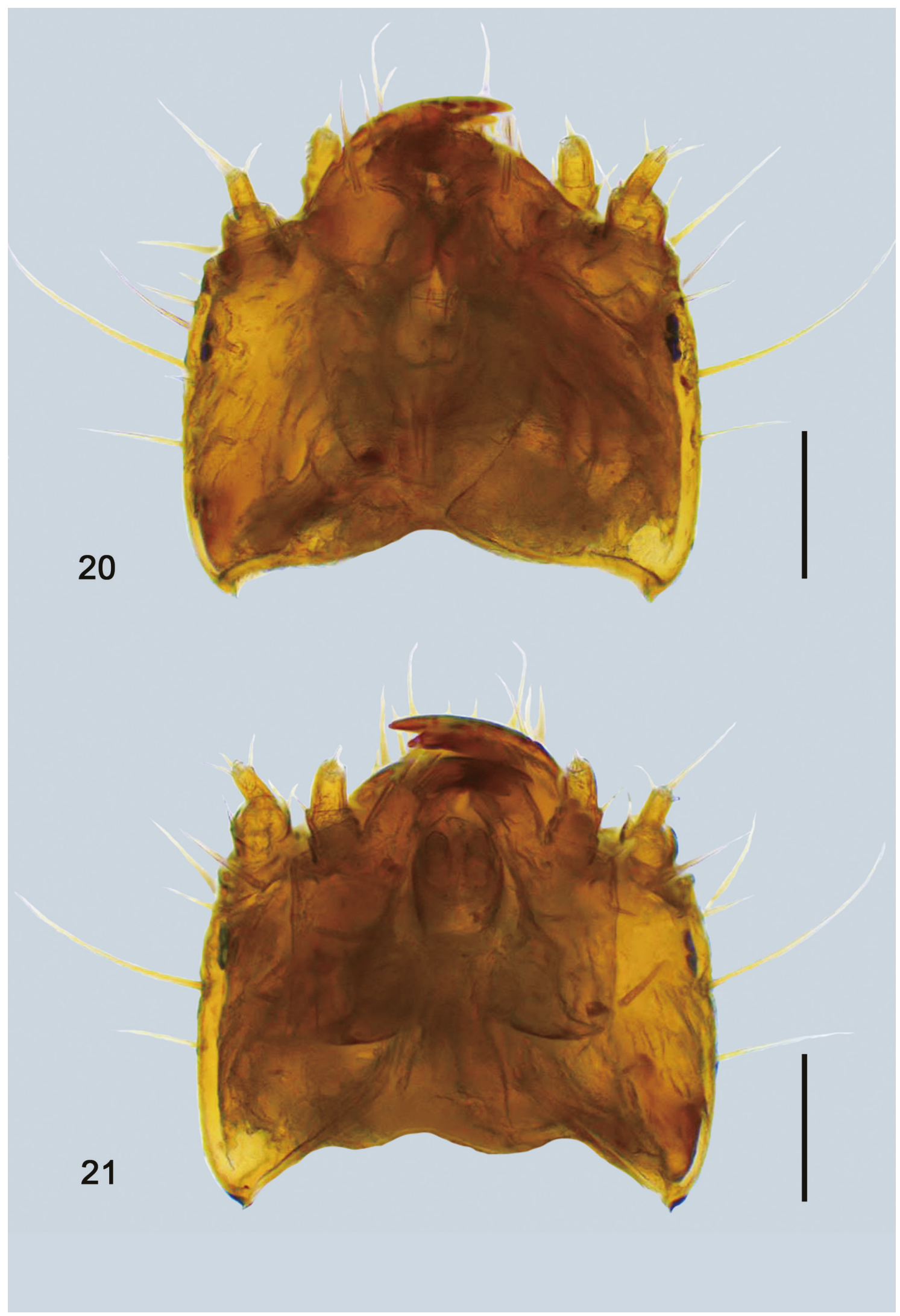

Figs 20-21. Head of first-instar larva of Trictenotoma formosana Kriesche, 1919. 20. Dorsal view. 21. Ventral view. Scale bars: $0.1 \mathrm{~mm}$. 


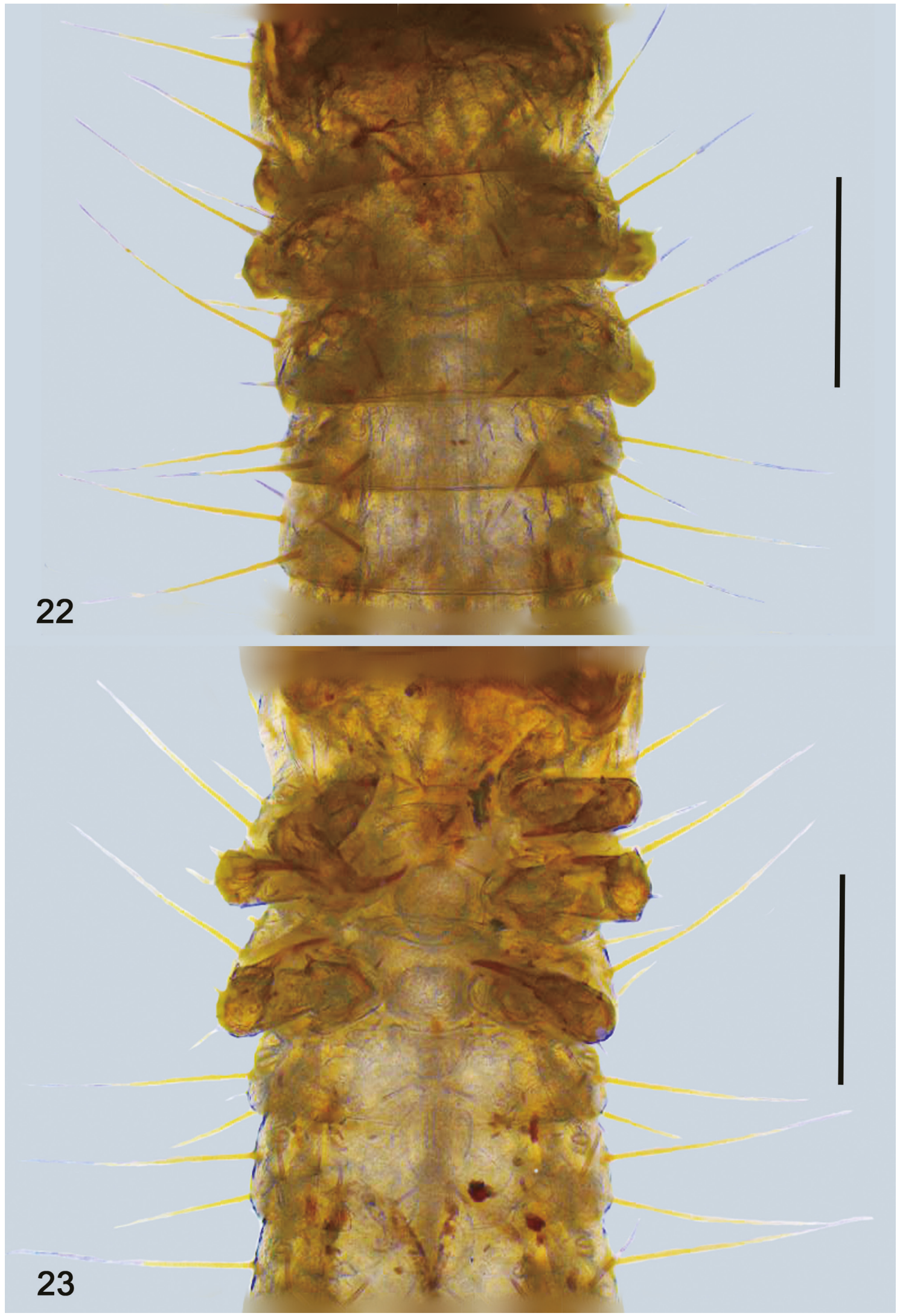

Figs 22-23. Thorax and abdominal segments 4-5 of first instar larva of Trictenotoma formosana Kriesche, 1919. 22. Dorsal view. 23. Ventral view. Scale bars: $0.2 \mathrm{~mm}$. 


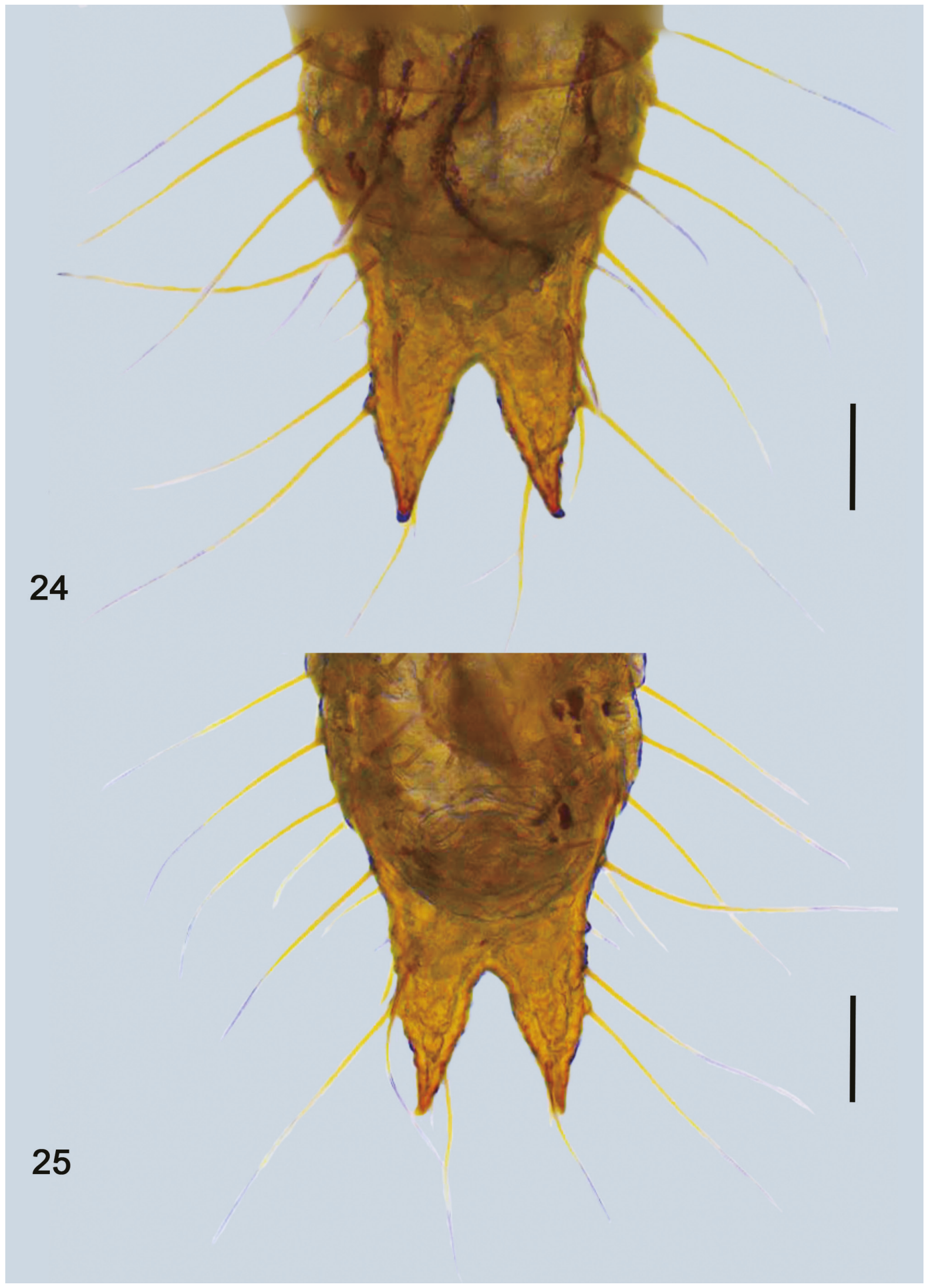

Figs 24-25. Abdominal segments 8-9 of first instar larva of Trictenotoma formosana Kriesche, 1919. 24. Dorsal view. 25. Ventral view. Scale bars: $0.1 \mathrm{~mm}$. 


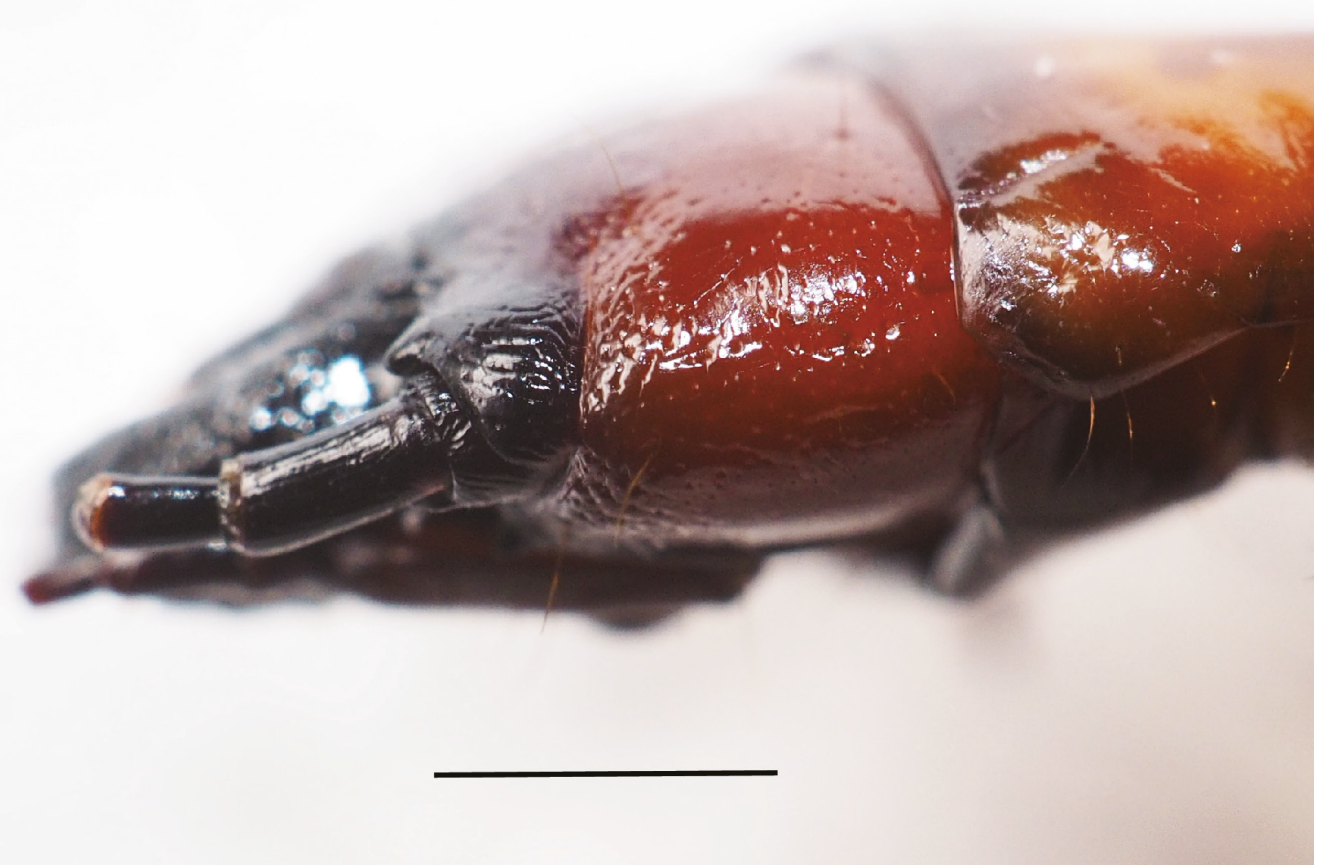

Figs 26-27. Head of larva of Trictenotoma formosana Kriesche, 1919 in lateral view. 26. First-instar larva; arrows indicate the 5 stemmata. 27. Last-instar larva. Scale bars: $26=0.1 \mathrm{~mm} ; 27=3 \mathrm{~mm}$. 
on lateral margin of tergites; a pair of long setae on lateral-posterior part of tergites; ventral setae and spines on sternites $2-8$ (Fig. 23) as follows: six pairs of spines or setae spread on each sternite; a pair of spines on posterior-lateral parts of sternites; a pair of long setae on lateral margins; segment 9 with paired urogomphi, about $1.5 \times$ as long as segment 8 , hook-like and curved dorsally; urogomphal pit(s) and lip absent; dorsolateral setae of tergite 9 and urogomphi (Fig. 24) as follows: a pair on frontal-lateral margin of segment 9 , a pair between posterior margin of segment 9 and urogomphi, a pair on midlength of urogomphi, a pair of short setae on apex of urogomphi, sternite 9 with a half-circular ridge; ventral setae of sternite 9 and urogomphi (Fig. 25) as follows: two pairs on frontal margin of sternite 9, a pair of setae on middle plate of sternite 9 , a pair of long setae on lateral sternite 9 , a pair of short setae at $1 / 4$ length of urogomphi, a pair of long setae near midlength of urogomphi, a pair of long and a pair of short setae near apex of urogomphi.

\section{Description of the pupa (Figs 28-36)}

PupA. Adecticous-exarate, whitish to creamy with reddish to orange spiracles and darker mandibular apices. Body slightly to moderately flattened dorso-ventrally, with two distinct types of ornamentation: scattered, elongate setae on spherical protrusions and tergites; and extremely fine setae medially on most sternites and tergites (Figs 35-36).

HEAD. Deflexed ventrally, not visible in dorsal view. Eyes large and reniform, narrow, broadly shallowly emarginate anteriorly and posteriorly. Frons dorsally shallowly impressed, delicately transversely

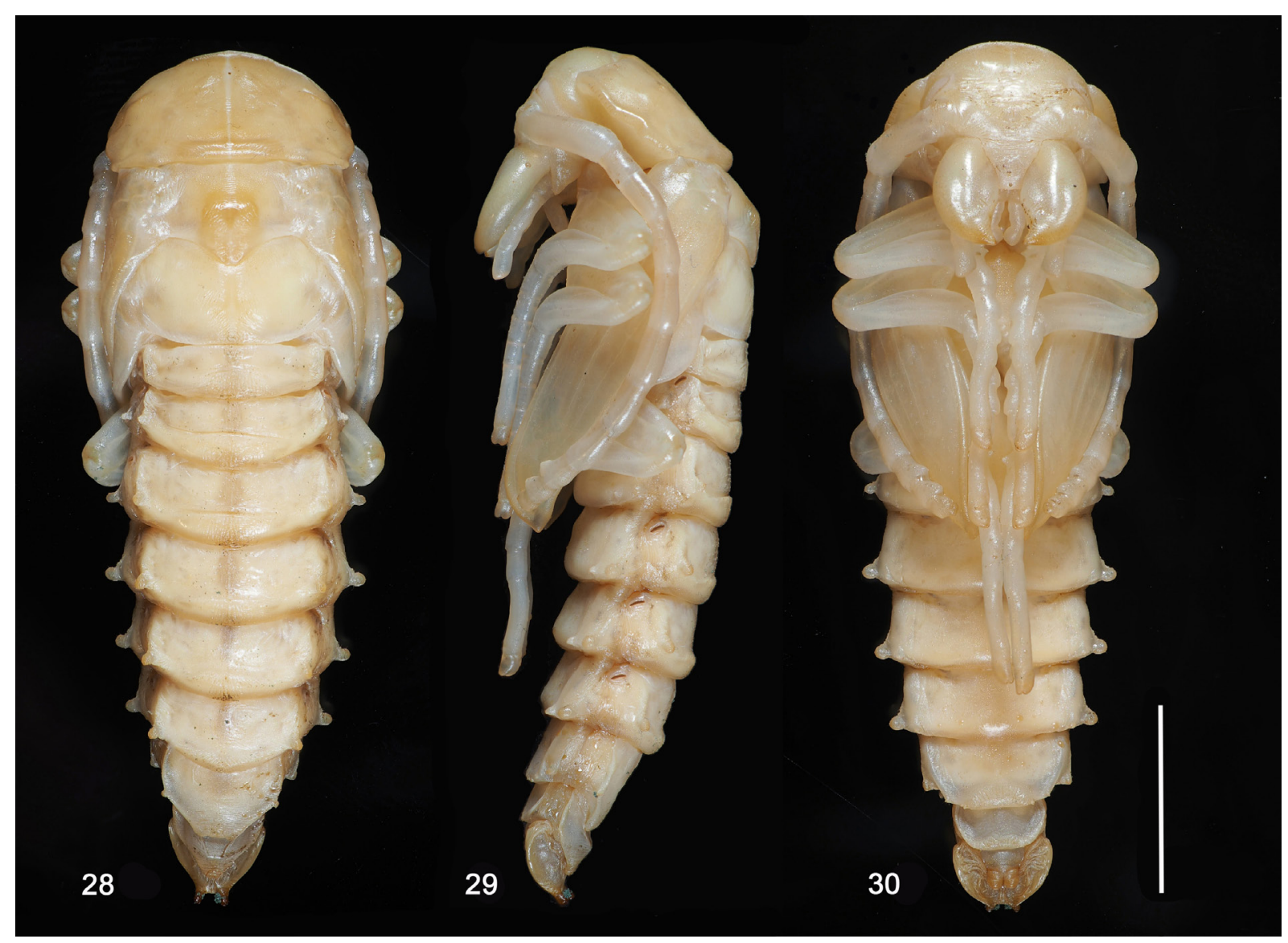

Figs 28-30. Pupa of Trictenotoma formosana Kriesche, 1919. 28. Dorsal view. 29. Lateral view. 30. Ventral view. Scale bar: $10 \mathrm{~mm}$. 


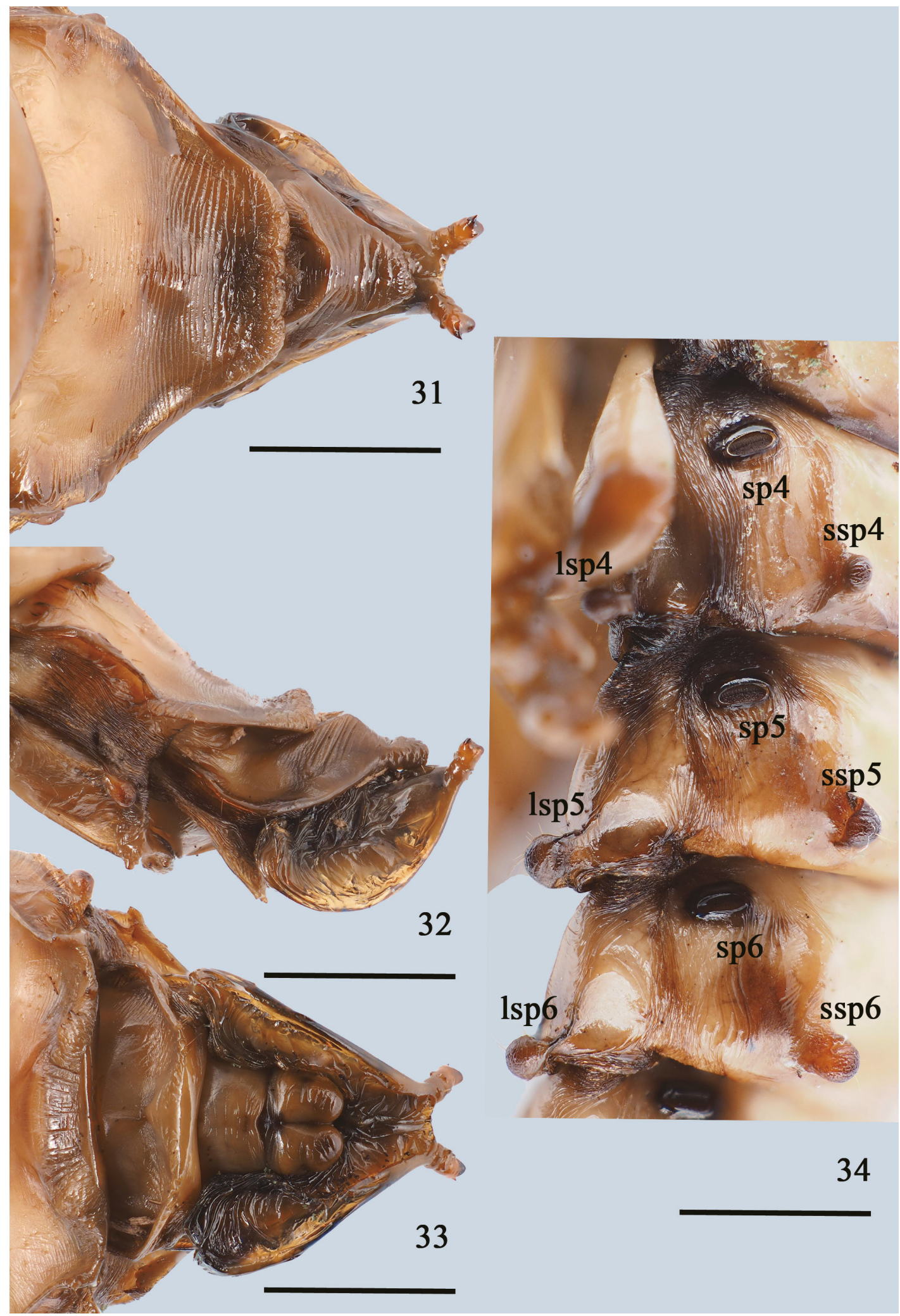

Figs 31-34. Abdominal segment 9 , spherical protrusions and spiracles of pupa of Trictenotoma formosana Kriesche, 1919. 31-33. Abdominal segment 9 ( 31 = dorsal view, $32=$ lateral view, $33=$ ventral view $)$. 34. Spherical protrusions and spiracles on segments 4-6, lateral view. Abbreviations: $\mathrm{sp}=$ spiracle; $1 \mathrm{sp}=$ lateral spherical protrusion; $\mathrm{ssp}=$ second spherical protrusion. Scale bars: $31-33=3 \mathrm{~mm} ; 34=2 \mathrm{~mm}$. 


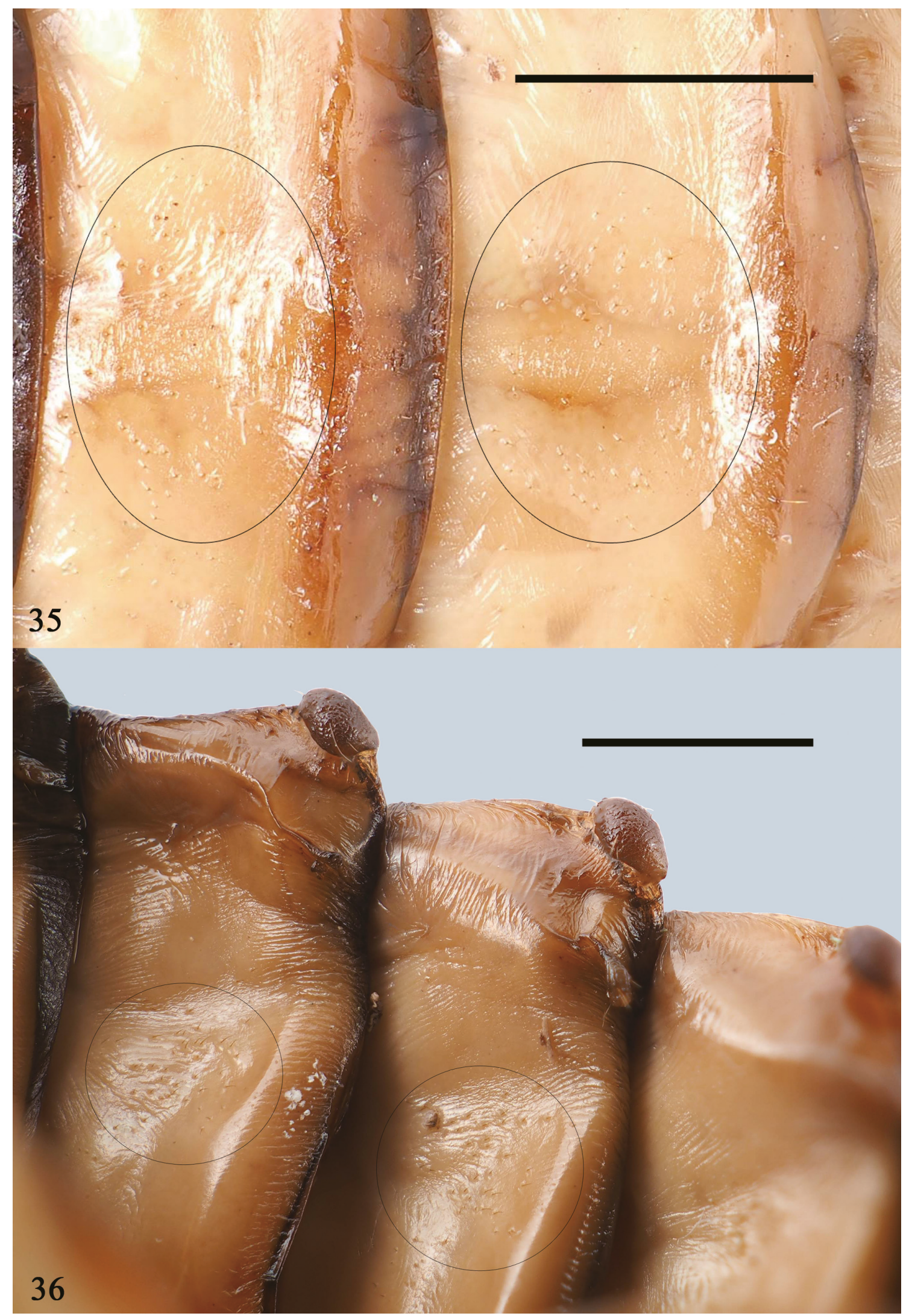

Figs 35-36. Extremely fine setae on abdominal segments of pupa of Trictenotoma formosana Kriesche, 1919. 35. Setae on tergites 4-5. 36. Setae on sternites 4-5. Scale bars: $3 \mathrm{~mm}$. 
HU F.-S. et al., Comparative morphology of immature Trictenotomidae

wrinkled between antennal insertions. Clypeus and labrum delicately transversely wrinkled. Mandibles externally semioval, apices pointed, internally sinuous. Antennae long, extending to third abdominal ventrite.

Thorax. Pronotum trapezoidal, with moderately curved lateral and anterior margins; lateral margins irregularly carinate; disc with two median longitudinal carinae. Mesonotum with scutellar shield; mesonotum with irregularly wrinkled median protrusion; elytra well developed. Metathoracic notum oval, longer than mesothoracic notum and abdominal ventrites 1-6; anterior margin with semicircular groove.

ABDomen. Ventrites 1-6 subrectangular (tergite 6 broadly rounded posteriorly); widest at segment 3 , narrowest at segment 6; segments each with a lateral ridge which has a spherical protrusion (weakly developed on segments 1 and 2) (Fig. 34); tergites 2-7 with second spherical protrusion (Fig. 34) on postero-lateral margin (weakly developed on tergite 2); $2-5$ long setae on each spherical protrusion. Tergites 1 and 2 laterally wrinkled in dorsal view; tergites 2 and 3 with a median longitudinal groove; sternite 7 subrectangular, with four small protrusions on posterior margin; tergite 7 subpentagonal, with some longitudinal wrinkles; group of about 70 extremely fine setae medially on tergites 1-6 (Fig. 35), about 30 on tergite 7; about 70 extremely fine setae on sternite 3 (first visible)-6; setae on sternite separated into 3 distinct groups, a grouping of about 30 setae on each side of sternite and about 10 setae spread medially on sternite (Fig. 36). Sternite 9 with two oval, wrinkled and flake-like lateral protrusions; protrusion apex narrow and spherical. Urogomphi (Figs 31-33) short and columnar. Abdominal spiracles (Fig. 34) oblong, prominent, with strongly sclerotized peritreme, present on segments 1-6.

\section{Discussion}

\section{Differences between first-instar and last-instar larvae}

The number of stemmata in beetle larvae is used widely in morphology-based phylogenetic analysis (Grebennikov \& Scholtz 2004; Ślipiński et al. 2009; Lawrence et al. 2011; Hua et al. 2014). Based on our study, the first-instar larva of T. formosana has 5 stemmata on each side: an anterior column of 3 and a posterior column of 2 (Fig. 26). However, stemmata are absent from the head of the last-instar larva (Fig. 27). The stemmatal configuration seen in the first-instar larva of $T$. formosana resembles that of the mature larva in many taxa within the "salpingid group" (e.g., most Salpingidae, eurypine and hemipepline Mycteridae, Pythidae, Pyrochroinae and Boridae (Boros Herbst, 1797)) (Young 1991a, 1991b, 1991c, 1991d; Pollock 1991; Pollock \& Lawrence 1995). The ontogenetic importance and phylogenetic signal of this phenomenon remain unknown.

The presence of a series of longitudinal ridges on the thoracic and abdominal tergites and sternites of larval Trictenotomidae is one of the most important diagnostic features of larvae of this family (Pollock \& Lawrence 1995). Examination of first-instar larvae revealed that these ridges are absent from early trictenotomid larvae, at least for T. formosana. Instead, long setae are present in the first-instar larvae where the ridges are present in last instars. Hence, we hypothesize that the longitudinal ridges of the last-instar larva and the setae of the first-instar larva might be homologous structures.

\section{Revised diagnosis of mature larva of Trictenotomidae (Trictenotoma)}

Based on the description of T. childreni by Gahan (1908), Pollock \& Lawrence (1995) proposed the following as distinguishing features of larval Trictenotomidae in their key to genera of larvae of Pythidae: urogomphi simple, approximate and subparallel; abdominal tergites 1-8 and sternites 2-8 with longitudinal ridges; base of sternite 9 with row of asperities (about 15 per side); and legs setose. All of these structural features agree with those exhibited by $T$. formosana. Based on fresh specimens of $T$. formosana, we here revise the diagnostic features of mature larva of Trictenotomidae: lack of stemmata, 
antennal sensorium, urogomphal pit(s) or urogomphal lip, presence of a series of short, longitudinal ridges on the dorsal and ventral surfaces of meso- and metathorax, and abdominal tergites 1-8, sternites $1-8$ and anterior margin of sternite 9 with paired, slightly arcuate row of $12-15$ asperities, setose legs and the relatively short, upturned urogomphi.

So far, larvae of only two species of Trictenotomidae have been described, both in the genus Trictenotoma (T. childreni and T. formosana), with over 110 years between descriptions. The larva of Autocrates remains unknown. The discovery and description of the larva of Autocrates will undoubtedly help to define and refine the distinguishing features of larval trictenotomids more accurately.

\section{Recent phylogenetic placement of Trictenotomidae}

Pollock \& Telnov (2010) summarized the history of the classification and phylogenetic position of Trictenotomidae. Despite the odd placement of the family near the Cerambycidae within an enlarged Chrysomeloidea by Ferrer \& Drumont (2003), evidence up to that time provided a solid position somewhere in the "salpingid group" of families (sensu Watt 1987 and Pollock 1994). This grouping includes Pythidae, Salpingidae, Boridae, Pyrochroidae and Trictenotomidae. Though there was only the single partially described larva by Gahan (1908) available for study (or, perhaps more accurately, its description), larval characteristics were used in some of these more recent treatments. Based on immature features of Trictenotoma, as described by Gahan (1908), Beutel \& Friedrich (2005) supported the earlier proposed sister group relationship between Trictenotomidae and Pythidae. Since 2010, several major comprehensive attempts to reconstruct the phylogeny of Coleoptera have been published. Two of these that have direct relevance to the phylogenetic placement of Trictenotoma and Autocrates are discussed below. One is more traditional, using morphological features of larvae and adults (Lawrence et al. 2011) and the others provide valuable complementary studies, using several nuclear genes (McKenna et al. 2015; Batelka et al. 2016; Zhang et al. 2018). As will be shown, all studies confirm the placement of Trictenotomidae in the Tenebrionoidea.

In their effort to elucidate phylogenetic relationships within Coleoptera, Lawrence et al. (2011) used 344 adult- and 172 larval-stage morphological characters, representing 314 family-group taxa. Adult(s) of T. childreni and the larval description of T. childreni by Gahan (1908) were used as sources of the character state coding for Trictenotomidae. The results were somewhat different from most other recent classifications. The "salpingid group" was more or less intact, but with the additions of taxa traditionally placed in Anthicidae, Lymexylidae, Oedemeridae and Mycteridae. Interestingly, Trictenotomidae was recovered within a monophylum with genera of Zopheridae sensu lato. The one larval feature supporting this clade is the presence of a single urogomphal pit. This character was thought to be homplasious by Lawrence et al. (2011), as it also was used in support of part of the "salpingid group".

Sequence data from eight nuclear genes were used by McKenna et al. (2015) to produce Bayesian and maximum-likelihood cladograms for Tenebrionoidea. Trictenotoma sp. was one of 367 species representing up to 172 families, used for the assessment. The Bayesian tree strongly supported the monophyly of the "salpingid group", part of which revealed Trictenotomidae as the sister taxon to (a polyphyletic) Salpingidae + Pythidae. Boridae and Pyrochroidae are also part of this group. However, the maximum likelihood tree of McKenna et al. (2015) has a different topology, in which the "salpingid group" is polyphyletic. In this tree, Trictenotomidae is the sister group to Prostomidae + Oedemeridae, which collectively are the sister group to Boridae.

In a conceptually similar study, 95 nuclear protein-coding genes of 373 species in 124 families were used by Zhang et al. (2018) and the result highlights a close relationship between Boridae and Trictenotomidae. Contrary to the results of McKenna et al. (2015), Pyrochroidae is not considered a "salpingid group" member according to the cladogram of Zhang et al. (2018). The molecularly-based results produced 
HU F.-S. et al., Comparative morphology of immature Trictenotomidae

by McKenna et al. (2015) and Zhang et al. (2018) indicated that a phylogenetic relationship of Trictenotomidae with other "salpingid group" families is clear, but amore focused assessment of "salpingid group" taxa (including more extensive sequencing of Trictenotomidae) is needed in order to reach a better understanding of the relationships within this family-group of Tenebrionoidea.

While our study does not include a new phylogenetic analysis based on morphological characters of the first- or last-instar larva or pupa of $T$. formosana, the features discovered in these three life cycle stages present an opportunity for new character analysis (e.g., from the first-instar) and corroborate the characters and results used in past analyses based on the last-instar larva of $T$. childreni. The single larval specimen of T. childreni, presumably collected in the early 1900s and described in Gahan (1908), has been ignored by some authors, especially those who support placement of Trictenotomidae near Cerambycidae. On the other hand, the description of Gahan (1908) has been very critical in supplying larval-stage evidence supporting placement of Trictenotoma (and Trictenotomidae) in the Tenebrionoidea. The newly collected, reared and studied material of $T$. formosana documented in this paper and by Lin \& $\mathrm{Hu}(2018,2019)$ has allowed a far clearer basis for classifying this historically enigmatic group of beetles. As was said by Gahan (1908: 275): "In view of the divergence of the opinions that were at one time held in regard to the systematic position of the Trictenotomidae, a knowledge of the larvae of this family must prove to be interesting...". Placement of the family within Tenebrionoidea is fully supported, and the characters from the immature stages (as well as molecular data) will hopefully allow a more solid placement within this superfamily.

\section{Acknowledgments}

The authors are highly indebted to Mr. Zong-Ru Lin (Taichung City, Taiwan) for specimens provided for this study. The first author also thanks Dr. Hou-Feng Li (Taichung City, Taiwan) for access to equipment used for examination and photography.

\section{References}

Batelka J., Kundrata R. \& Bocak L. 2016. Position and relationships of Ripiphoridae (Coleoptera: Tenebrionoidea) inferred from ribosomal and mitochondrial molecular markers. Annales Zoologici 66: 113-123. https://doi.org/10.3161/00034541ANZ2016.66.1.008

Beutel R.G. \& Friedrich F. 2005. Comparative study of larvae of Tenebrionoidea (Coleoptera: Cucujiformia). European Journal of Entomology 102: 241-264. https://doi.org/10.14411/eje.2005.037

Crowson R.A. 1955. The Natural Classification of the Families of Coleoptera. Nathaniel Lloyd, London.

Crowson R.A. 1981. The Biology of Coleoptera. Academic Press, New York.

Drumont A. 2006. Contribution à l'étude des Trictenotomidae avec la description d'une nouvelle espèce d'Autocrates Thomson, 1860: A. maqueti n. sp. originaire du sud de la Chine (Coleoptera, Trictenotomidae). Les Cahiers Magellanes 61: 5-7.

Drumont A. 2016. Nouvelle contribution à l'étude du genre Autocrates Thomson, 1860 avec la description d'une nouvelle espèce du Vietnam: A. ivanovi n. sp. (Coleoptera: Trictenotomidae). Revista gaditana de Entomologia 7 (1): 25-36.

Drumont A. \& Telnov D. 2009. First record of Autocrates vitalisi Vuillet, 1912 from the island of Borneo (Coleoptera, Trictenotomidae). Bulletin de la Société royale belge d'Entomologie 145: 41-42.

Drumont A., Ivanov S., Do C. \& Telnov D. 2019. New distribution data in the genus Autocrates Thomson, 1860 (Coleoptera, Trictenotomidae). Lambillionea 129 (2): 101-104. 
Ferrer J. \& Drumont A. 2003. Considérations sur la vraie position systématique de la famille des Trictenotomidae Blanchard, 1845, sur base de l'étude de l'édéage (Coleoptera). Lambillionea 103: 457468.

Gahan C.J. 1908. On the larvae of Trictenotoma childreni, Gray, Melittomma insulare, Fairmaire, and Dascillus cervinus, Linn. Transactions of the Entomological Society of London 1908: 275-282.

Gebien H. 1911. Fam. Trictenotomidae. In: Junk W. \& Schenkling S. (eds) Coleopterorum Catalogus. Pars 37: 741-742. W. Junk, Berlin.

Gray G. 1832. The Class Insecta Arranged by the Baron Cuvier, with Supplementary Additions to Each Order by Edward Griffith, F.L.S., A.S., \& c. and Edward Pidgeon, Esq. and Notices of New Genera and Species by George Gray, Esq. Whittaker, Treacher and Co., London.

Grebennikov V.V. \& Scholtz C.H. 2004. The basal phylogeny of Scarabaeoidea (Insecta: Coleoptera) inferred from larval morphology. Invertebrate Systematics 18:321-348. https://doi.org/10.1071/IS03013

Hadley A. 2010. CombineZP. Available from https://combinezp.software.informer.com/download [accessed 17 Oct. 2019].

Hua Y., Beutel R.G., Ge S.-Q., Nie R.-E. \& Yang X.-K. 2014. The morphology of galerucine and alticine larvae (Coleoptera: Chrysomelidae) and its phylogenetic implications. Arthropod Systematics \& Phylogeny 72 (2): 75-94.

Kergoat G.J., Soldati L., Clamens A.-L., Jourdan H., Jabbour-Zahab R., Genson G., Bouchard P. \& Condamine F.L. 2014. Higher level molecular phylogeny of darkling beetles (Coleoptera: Tenebrionidae). Systematic Entomology 39: 486-499. https://doi.org/10.1111/syen.12065

Kriesche R. 1919. Bemerkungen über einige Trictenotomiden. (Coleopt.). Archiv für Naturgeschichte 82 A (11): 150.

Lameere A. 1916. Trictenotomidae (Col.) de la collection du Muséum de Paris. Bulletin du Muséum national d'histoire naturelle 22: 84-91.

Lawrence J.F., Ślipiński A., Seago A.E., Thayer M.K., Newton A.F. \& Marvaldi A.E. 2011. Phylogeny of the Coleoptera based on morphological characters of adults and larvae. Annales Zoologici 61 (1): 1-217. https://doi.org/10.3161/000345411X576725

Lin Z.-R. \& Hu F.-S. 2018. Notes on the oviposition of Trictenotoma formosana Kriesche, 1919 under the artificial conditions, with an observation of the hatching (Coleoptera: Trictenotomidae). Taiwanese Journal of Entomological Studies 3 (2): 34-37.

Lin Z.-R. \& Hu F.-S. 2019. Unravel the century old mystery of Trictenotomidae: Natural history and rearing technique for Trictenotoma formosana Kriesche, 1919 (Coleoptera: Trictenotomidae). Taiwanese Journal of Entomological Studies 4 (1): 1-8.

McKenna D.D., Wild A.L., Kanda K., Bellamy C.L., Beutel R.G., Caterino M.S., Farnum C.W., Hawks D.C., Ivie M.A., Jameson M.L., Leschen R.A.B., Marvaldi A.E., McHugh J.V., Newton A.F., Robertson J.A., Thayer M.K., Whiting M.F., Lawrence J.F., Ślipiński A., Maddison D.R. \& Farrell B.D. 2015. The beetle tree of life reveals that Coleoptera survived end-Permian mass extinction to diversify during the Cretaceous terrestrial revolution. Systematic Entomology 40: 835-880.

https://doi.org/10.1111/syen.12132

Pollock D.A. 1991. Natural history, classification, reconstructed phylogeny, and geographic history of Pytho Latreille (Coleoptera: Heteromera: Pythidae). Memoirs of the Entomological Society of Canada 154: 1-104. 
HU F.-S. et al., Comparative morphology of immature Trictenotomidae

Pollock D.A. 1994. Systematic position of Pilipalpinae (Coleoptera: Tenebrionoidea) and composition of Pyrochroidae. The Canadian Entomologist 126: 512-532.

Pollock D.A. \& Lawrence J.F. 1995. Review of Anaplopus Blackburn (Coleoptera: Pythidae), with comments on constituents and systematics of Pythidae. In: Pakaluk J. \& Ślipiński A. (eds) Biology, Phylogeny and Classification of Coleoptera: Papers Celebrating the $80^{\text {th }}$ Birthday of Roy A. Crowson: 449-472. Muzeum i Institut Zoologii Polskiej Akademii Nauk, Warsaw.

Pollock D. \& Telnov D. 2010. Trictenotomidae Blanchard, 1845. In: Leschen R.A.B., Beutel R.G. \& Lawrence J.F. (eds) Coleoptera, Beetles. Volume 2. Morphology and Systematics (Elateroidea, Bostrichiformia, Cucujiformia partim). Arthropoda Insecta. Handbook of Zoology: 704-708. De Gruyter, Berlin and New York. https://doi.org/10.1515/9783110911213.708

Ślipiński A., Tomaszewska W. \& Lawrence J.F. 2009. Phylogeny and classification of Corylophidae (Coleoptera: Cucujoidea) with descriptions of new genera and larvae. Systematic Entomology 34: 409433. https://doi.org/10.1111/j.1365-3113.2009.00471.x

Telnov D. 1999. Zoogeographie der Trictenotomidae Blanchard, 1845 (Coleoptera: Heteromera). 7. DPU zinātniskās konferences rakstu krājums A9: 95-97. https://doi.org/10.13140/RG.2.1.1250.0324

Telnov D. \& Lee J.E. 2008. Autocrates maqueti Drumont, 2006 - new to the fauna of the Korean Peninsula (Coleoptera: Trictenotomidae). Latvijas Entomologs 46: 72-75.

Watt J.C. 1987. The family and subfamily classifications of New Zealand genera of Pythidae and Scraptiidae (Coleoptera). Systematic Entomology 12: 111-136.

https://doi.org/10.1111/j.1365-3113.1987.tb00552.x

Westwood J.O. 1848: The Cabinet of Oriental Entomology; Being a Selection of some of the Rarer and More Beautiful Species of Insects, Natives of India and the Adjacent Islands, the greater Portion of which are now for the first Time Described and Figured. William Smith, London.

Young D.K. 1991a. Boridae (Tenebrionoidea). In: Stehr F.W. (ed.) Immature Insects. Volume 2: $537-$ 539. Kendall/Hunt Publishing Company, Dubuque, Iowa.

Young D.K. 1991b. Pythidae (Tenebrionoidea). In: Stehr F.W. (ed.) Immature Insects. Volume 2: 539541. Kendall/Hunt Publishing Company, Dubuque, Iowa.

Young D.K. 1991c. Pyrochroidae (Tenebrionoidea). In: Stehr F.W. (ed.) Immature Insects. Volume 2: 541-544. Kendall/Hunt Publishing Company, Dubuque, Iowa.

Young D.K. 1991d. Salpingidae (Tenebrionoidea). In: Stehr F.W. (ed.) Immature Insects. Volume 2: 549-551. Kendall/Hunt Publishing Company, Dubuque, Iowa.

Zhang S.-Q., Che L.-H., Li Y., Liang D., Pang H., Ślipiński A. \& Zhang P. 2018. Evolutionary history of Coleoptera revealed by extensive sampling of genes and species. Nature Communications 9 (205): 1-11. https://doi.org/10.1038/s41467-017-02644-4

Manuscript received: 12 December 2019

Manuscript accepted: 11 February 2020

Published on: 5 May 2020

Topic editor: Nesrine Akkari

Section editor: Max Barclay

Desk editor: Kristiaan Hoedemakers 
Printed versions of all papers are also deposited in the libraries of the institutes that are members of the EJT consortium: Muséum national d'histoire naturelle, Paris, France; Meise Botanic Garden, Belgium; Royal Museum for Central Africa, Tervuren, Belgium; Royal Belgian Institute of Natural Sciences, Brussels, Belgium; Natural History Museum of Denmark, Copenhagen, Denmark; Naturalis Biodiversity Center, Leiden, the Netherlands; Museo Nacional de Ciencias Naturales-CSIC, Madrid, Spain; Real Jardín Botánico de Madrid CSIC, Spain; Zoological Research Museum Alexander Koenig, Bonn, Germany; National Museum, Prague, Czech Republic. 